\title{
Zasady stosowania dootrzewnowej chemioterapii w hipertermii (HIPEC) w leczeniu nowotworów złośliwych powierzchni otrzewnej w połączeniu z zabiegami cytoredukcyjnymi: zalecenia krajowe
}

\author{
Piotr Rutkowski ${ }^{1}$, Beata Śpiewankiewicz ${ }^{1}$, Krzysztof Herman, \\ Tomasz Jastrzębski, Józef Kładny, Zbigniew Kojs, \\ Maciej Krzakowski, Wojciech Polkowski, Lucjan Wyrwicz, \\ Piotr Wysocki, Marcin Zdzienicki, Wojciech Zegarski
}

Leczenie nowotworów powierzchni otrzewnej stanowi istotny problem w onkologii. Wykazano, że skojarzenie maksymalnej cytoredukcji chirurgicznej z dootrzewnową chemioterapią w hipertermii (HIPEC; hyperthermic intraoperative peritoneal chemotherapy) może prowadzić do długotrwałej kontroli choroby lub wydłużenia przeżyć u odpowiednio wybranych chorych. Celem niniejszego opracowania są zalecenia dla optymalnego zakresu wskazań i sposobu prowadzenia HIPEC w Polsce².

\section{Polish clinical practice guidelines on Hyperthermic Intraperitoneal Chemotherapy (HIPEC) with Cytoreductice Surgery (CRS) in peritoneal malignancy treatment}

The management of peritoneal surface malignancy is a significant clinical problem. The hyperthermic intraperitoneal chemotherapy (HIPEC) combined with cytoreductive surgery seems to be the most promising method, leading to better local control or improved overall survival in selected patients with a peritoneal neoplasm. In this paper the authors present a consensus for the optimal indications and technical guidelines for performing HIPEC in Poland.

NOWOTWORY Journal of Oncology 2014; 64, 6: 518-524

Słowa kluczowe: nowotwory powierzchni otrzewnej, dootrzewnowa chemioterapia w hipertermii, cytoredukcja Key words: peritoneal surface malignancies, hiperthermic intraperitoneal chemotherapy, cytoreductive surgery

\section{Wstęp}

Leczenie śródotrzewnowego rozsiewu nowotworów wywodzących się z przewodu pokarmowego, żeńskich narządów płciowych oraz pierwotnych wieloogniskowych nowotworów otrzewnej (międzybłoniak, śluzak rzekomy) stanowi istotny problem w onkologii. Ta grupa chorych jest dość liczna i obejmuje około $15 \%$ chorych na raka jelita grubego i około $40 \%$ chorych na raka żołądka, a także znaczną część populacji pacjentek chorych na raka jajnika. Mechanizm ograniczonego przerzutowania do jamy otrzewnowej wybranych nowotworów nie został ustalony. Należy podkreślić, że chorzy z takimi rozpoznaniami rokują źle, a dostępne tradycyjne metody leczenia przeciwnowotworowego są zwykle mało skuteczne. Dodatkowo zajęcie nowotworowe otrzewnej może prowadzić do upośledzenia funkcji przewodu pokarmowego, co negatywnie wpływa na przeżycia chorych i uniemożliwia racjonalne prowadzenie leczenia przyczynowego w przypadku występowania wielopoziomowej niedrożności. Zarówno leczenie systemowe, jak i nieradykalne próby leczenia chirurgicznego zwykle nie pozwalają

\footnotetext{
${ }^{1}$ Dwóch pierwszych autorów w równym stopniu przyczyniło się do powstania tej pracy

${ }^{2}$ Przedstawione stanowisko zostało uzgodnione 29 sierpnia 2014 roku przez Polskie Towarzystwo Chirurgii Onkologicznej, Polskie Towarzystwo Onkologii Klinicznej i Polskie Towarzystwo Ginekologii Onkologicznej oraz konsultantów krajowych w dziedzinie chirurgii onkologicznej, onkologii klinicznej i ginekologii onkologicznej
} 
na uzyskanie trwałej remisji lub wyraźnego przedłużenia przeżycia chorych, choć u części chorych intensywne leczenie redukujące narastanie wydzielania płynu puchlinowego (lek moczopędny z grupy antagonistów aldosteronu oraz powtarzalne paracentezy) umożliwiają wdrożenie ratunkowej chemioterapii systemowej o zmiennej skuteczności. W poszukiwaniu innych opcji terapeutycznych w latach 80. XX wieku podjęto próby jednoczesnego skojarzenia kilku metod. Początkowo u chorych na raka jajnika połączono śródotrzewnową chemioterapię z chirurgicznym leczeniem cytoredukcyjnym. Następnie do tego schematu dodano hipertermię, której celem było polepszenie penetracji cytotoksycznych leków stosowanych miejscowo i zwiększenie ich przeciwnowotworowego działania przy jednoczesnym ograniczeniu toksyczności systemowej. Obecnie obowiązującą zasadą jest traktowanie otrzewnej jako jednego narządu i uwzględnienie maksymalnego leczenia cytoredukcyjnego w skojarzeniu z chemioterapią (i hipertermią) w wyselekcjonowanych przypadkach nowotworów otrzewnej o ograniczonym zaawansowaniu. Współcześnie maksymalna cytoredukcja chirurgiczna (CCRS - complete cytoreductive surgery) i dootrzewnowa chemioterapia w warunkach hipertermii (hyperthermic intraperitoneal chemotherapy - HIPEC) stanowią standardowe postępowanie w rozsiewie śródotrzewnowym kilku typów nowotworów i są nadal przedmiotem badań w innych rozpoznaniach [1, 2]. Należy podkreślić, iż dotychczas nie przeprowadzono badań z randomizacją chorych wskazujących bezspornie, że HIPEC prowadzi do poprawy rokowania w ogólnej grupie pacjentów z rozsiewem sródotrzewnowym. Tym samym metodę tę stosuje się przy rygorystycznym przestrzeganiu zasad wielospecjalistycznej kwalifikacji i wykluczeniu uogólnienia choroby poza otrzewną (z wyjątkiem ograniczonych przerzutów do wątroby raka jelita grubego). Przedmiotem niniejszych zaleceń opartych na aktualnej wiedzy jest stanowisko przedstawicieli kilku specjalności onkologicznych w Polsce odnośnie stosowania dootrzewnowej chemioterapii w hipertermii w leczeniu nowotworowego zajęcia otrzewnej.

\section{Technika CCRS plus HIPEC, ocena przed- i śródoperacyjna, powikłania, metody}

Za niezbędny element operacji uważane jest wycięcie wszystkich widocznych makroskopowo śródotrzewnowych zmian nowotworowych. Jeżeli jest to niemożliwe, dopuszczalne jest pozostawienie zmian o wielkości do 2,5 mm [3]. Penetracja chemioterapeutyków w głąb tkanek jest ograniczona do ok. 3-5 mm i z tego powodu wszystkie guzy o większych średnicach powinny zostać usunięte [4, 5]. Nie bez znaczenia jest także uwolnienie ewentualnych zrostów śródotrzewnowych, których obecność utrudnia perfuzję wewnątrz jamy brzusznej. Dla uzyskania całkowitej cytoreducji konieczna jest często resekcja otrzewnej wraz ze zmianami nowotworowymi (peritonektomia całkowita lub częściowa, np. przeponowa, miedniczna). Niezbędne jest również wycięcie sieci większej i mniejszej oraz więzadła obłego wątroby i pępka. Postępowanie takie jest obarczone co prawda wysokim odsetkiem powikłań, jednak prowadzi do zwiększenia odsetka resekcji radykalnych i poprawia odległe wyniki leczenia, zwiększając odsetek wieloletnich przeżyć chorych [6]. Dopiero w czasie ostatniego etapu zabiegu operacyjnego wykonywana jest perfuzja otrzewnej poprzez skojarzenie chemioterapii dootrzewnowej z synergistycznie/addytywnie działającą hipertermią. Wykazano, że HIPEC daje lepsze wyniki niż jedynie śródotrzewnowa („zimna”) chemioterapia lub wyłącznie hipertermia [7]. Perfuzja dootrzewnowa w hipertermii może być wykonywana metodą otwartą (technika „Koloseum”) lub zamkniętą, po zamknięciu powłok jamy brzusznej. Schematy leków podawanych dootrzewnowo dobierane są indywidualnie, zależnie od choroby podstawowej oraz doświadczenia ośrodka. Najcześciej w ramach dootrzewnowego leczenia stosowana jest mitomycyna C, doksorubicyna, cisplatyna lub karboplatyna (przez 60-90 minut w temperaturze $41^{\circ} \mathrm{C}$ ) oraz oksaliplatyna (przez 30 minut w temperaturze $43^{\circ} \mathrm{C}$ ). Objętość roztworu cytostatyku (w soli fizjologicznej; tylko oksaliplatyna w 5\% roztworze glukozy) powinna wynosić $2 \mathrm{l} / \mathrm{m}^{2}$, a lek powinien być dawkowany również na powierzchnię ciała chorego [8].

Kluczową dla uzyskania optymalnego wyniku leczenia kwestią jest odpowiedni dobór chorych. Dobór ten następuje zarówno na etapie planowania leczenia, jak i śródoperacyjnie. Chorzy muszą być $w$ dobrym stanie ogólnym, bez istotnych innych obciążeń. Wstępna selekcja chorych kwalifikowanych do leczenia z wykorzystaniem HIPEC obejmuje wykluczenie pozaotrzewnowych przerzutów nowotworu, które nie byłyby objęte działaniem metody (pojedyncze resekcyjne przerzuty do wątroby u chorych na raka jelita grubego nie są przeciwwskazaniem). Kwalifikacja do procedury obejmuje wcześniejsze wykluczenie pozaotrzewnowych ognisk nowotworu oraz ocenę zaawansowania śródotrzewnowej choroby (tj. możliwości maksymalnej, bezpiecznej cytoredukcji) na podstawie wyniku badań spiralnej tomografii komputerowej z kontrastem (klatki piersiowej, jamy brzusznej i miednicy) i/lub rezonansu magnetycznego (jamy brzusznej i miednicy), określenie zakresu zmian w obrębie przewodu pokarmowego (gastroskopia i/lub kolonoskopia, w zależności od choroby podstawowej). Niektóre ośrodki dodatkowo stosują diagnostyczną laparoskopię. Należy oszacować ryzyko operacji, a także spodziewane przeżycie chorego. Drugi etap kwalifikacji do zastosowania HIPEC następuje w trakcie operacji. Powinien on uwzględniać możliwości techniczne wykonania maksymalnie radykalnej cytoredukcji, a także spodziewane wyniki i ewentualne skutki samej procedury (np. wpływ na przyszłą funkcję przewodu pokarmowego) [9-11]. Do oceny śródoperacyjnej zakresu zaawansowania zmian śródotrzewnowych wykorzystuje się wskaźnik zmian śródotrzewnowych (Peritoneal Cancer 


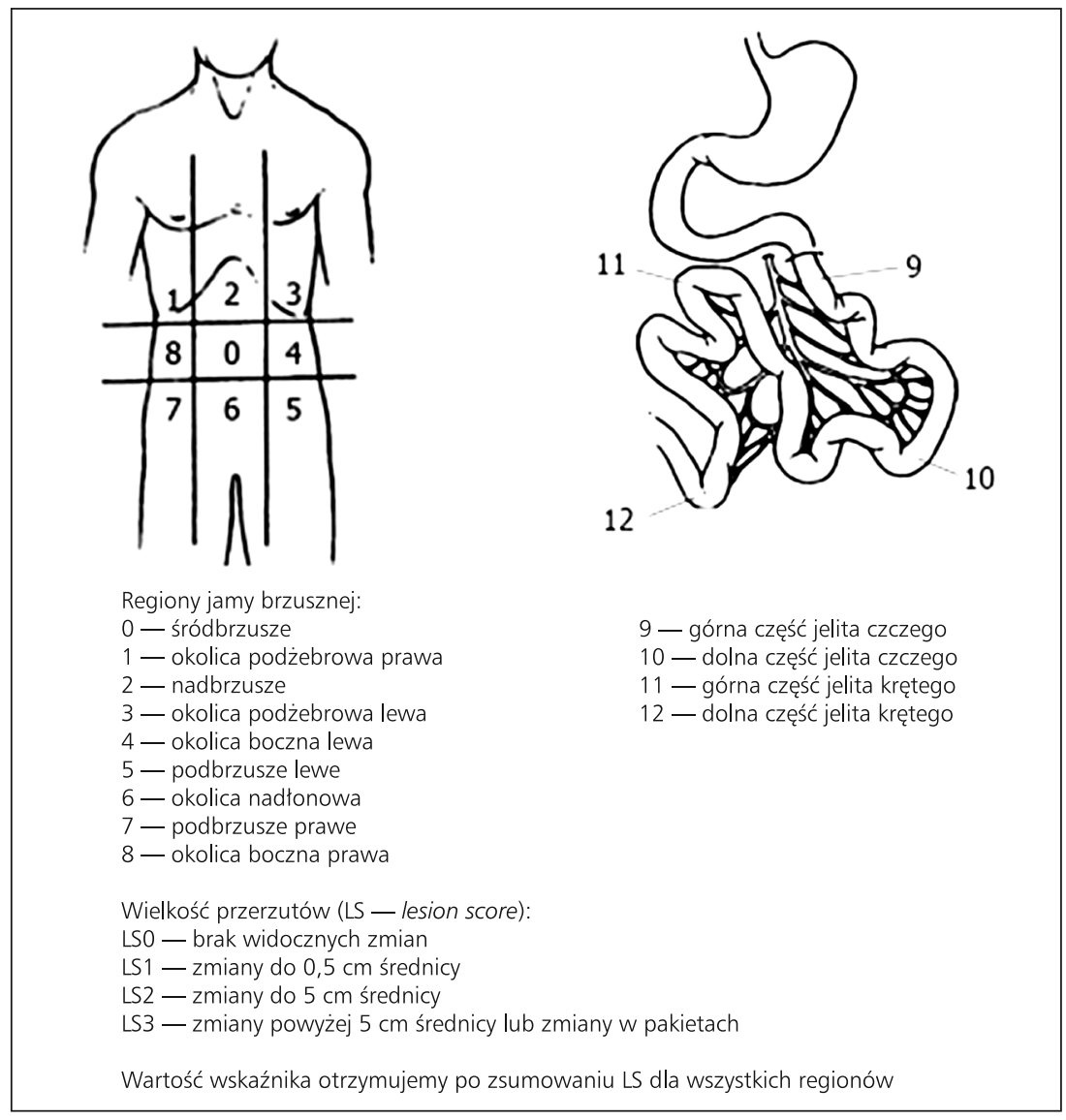

Rycina 1. Metoda oceny wskaźnika PCI (Peritoneal Cancer Index) wg Sugarbakera

Index - PCl); (ryc. 1), opisujący wielkość i zakres lokalizacji zmian w 13 regionach jamy brzusznej i wynoszący od 0 do 39 (każdy obszar może być oceniony liczbą 0-3 punktów, sumowane są wartości dla wszystkich obszarów). Do oceny stopnia maksymalnej cytoredukcji chirurgicznej wykorzystuje się skalę CCR (completeness of cytoreduction score) wg Jacqueta i Sugarbakera (tab. I), wynoszącą od CCRO (całkowita cytoredukcja bez zmian widocznych makroskopowo) do CCR3 (makroskopowe, rozległe zmiany). Powodem wprowadzenia skali CCR był fakt, iż obserwowano, że jedynie chorych, u których wykonano maksymalną (doszczętną) cytoredukcję CCR 0-1, należy kwalifikować śródoperacyjnie do HIPEC. Korzyści kliniczne z wykonywania HIPEC u chorych po nieradykalnej cytoredukcji (CCR2) są dyskusyjne, a po cytoredukcji CCR3 (pozostawiona tkanka nowotworu $>2,5 \mathrm{~cm}$ ) HIPEC jest przeciwwskazany (!).

Wykorzystanie tej metody wymaga doświadczenia stosujących ją lekarzy chirurgów, ginekologów onkologów i onkologów klinicznych, a także wielospecjalistycznego zaplecza diagnostycznego i leczniczego (np. referencyjnego oddziału intensywnej opieki medycznej, doświadczonego zespołu anestezjologicznego) [12] w ośrodku, w którym leczenie jest prowadzone. Wykonywanie procedury HIPEC powinno być więc ograniczone do kilku wielospecjalistycz-
Tabela I. Skala oceny skuteczności cytoredukcji CCR (Completeness of Cytoreduction Score)

\begin{tabular}{ll}
\hline $\begin{array}{l}\text { Stopień } \\
\text { cytoredukcji }\end{array}$ & Charakterystyka \\
\hline CCR 0 & $\begin{array}{l}\text { Brak widocznych makroskopowo } \\
\text { zmian nowotworowych }\end{array}$ \\
CCR 1 & $\begin{array}{l}\text { Zmiany resztkowe po cytoredukcji } \\
\text { o maksymalnym wymiarze } \\
\text { poniżej 2,5 mm }\end{array}$ \\
CCR 2 & $\begin{array}{l}\text { Zmiany resztkowe po cytoredukcji } \\
\text { o maksymalnym wymiarze powyżej 2,5 mm, } \\
\text { nie większe niż 2,5 cm } \\
\text { Zmiany resztkowe po cytoredukcji } \\
\text { o maksymalnym wymiarze } \\
\text { powyżej 2,5 cm }\end{array}$ \\
\hline
\end{tabular}

nych ośrodków referencyjnych w kraju, leczenie bowiem wiąże się $z$ dość istotną śmiertelnością (ocenianą na ok. 2-5\%), a także powikłaniami wynikającymi z chemioterapii i rozległości leczenia chirurgicznego (3-4 stopień toksyczności w około 1/3 przypadków) [2]. Konieczne jest więc monitorowanie odsetka powikłań oraz wyników odległych w danym ośrodku wykonującym HIPEC, najlepiej w postaci centralnego rejestru. Pomimo powikłań leczenia CCRS plus 
HIPEC wiąże się z poprawą jakości życia chorych, którzy najczęściej pozostają bez żadnego efektywnego leczenia, co prowadzi do niepowstrzymanej progresji nowotworu izgonu.

Według danych australijskich — pomimo wysokich kosztów procedury - wydłużenie przeżyć osiągane w chorobach, w których leczenie innymi metodami nie przynosi pożądanych skutków, powoduje, że procedura CCRS z HIPEC jest kosztowo efektywna [13]. Jednocześnie należy nadmienić, że brak referencyjnych badań z losowym doborem chorych powoduje, iż technologia tego typu nie może być oceniona pod kątem efektywności kosztowej w systemach ochrony zdrowia, zakładających wyliczenie dodatkowego kosztu za uzyskiwany efekt kliniczny, ponieważ faktyczny efekt kliniczny na przeżycie całkowite pacjenta nie został nigdy określony przez brak kohort porównawczych (vide kryteria QaLY w polskim systemie ochrony zdrowia). Tym samym $w$ takich systemach ochrony zdrowia procedura ta często pozostaje niedoszacowana lub nierefundowana z powodów proceduralnych. Jednocześnie bezsporne korzyści dla podgrupy pacjentów kwalifikowanych do HIPEC powodują, iż na obecnym etapie prowadzenie badań z randomizacją chorych nie wydaje się uzasadnione etycznie.

\section{Wskazania standardowe do stosowania HIPEC Pierwotne nowotwory otrzewnej}

1. Międzybłoniak otrzewnej (mesothelioma peritonei) CCRS w połączeniu z HIPEC pozwala uzyskać od $40 \%$ do ponad $60 \%$ przeżyć 5-letnich [6, 14-15]. Wyniki w znacznej mierze zależą od zakresu i doszczętności poprzedzającej dootrzewnową chemioterapię operacji cytoredukcyjnej. Przy tym rozpoznaniu śródotrzewnowo stosuje się zwykle doksorubicynę i cisplatynę [16], zaś systemowo przed operacją — cisplatynę i pemetreksed lub gemcytabinę.

2. Śluzak rzekomy otrzewnej (pseudomyxoma peritonei). Ognisko pierwotne zazwyczaj w wyrostku robaczkowym; rozpoznanie rzadkie (1 przypadek na 1-2 milionów mieszkańców/rok), 2. co do częstości (po rakowiaku) nowotwór wyrostka robaczkowego. CCRO i HIPEC z użyciem mitomycyny $C$ pozwala na uzyskanie wieloletnich przeżyć u większości chorych (10-letnie przeżycia ok. 60-70\%) [17-19]. Skojarzenie CCRS z HIPEC, szczególnie gdy możliwe jest wykonania maksymalnej cytoredukcji CCR 0-1, stanowi obecnie w tym wskazaniu postępowanie z wyboru. Wskaźnik PCI nie ma w śluzaku otrzewnej ustalonej wartości rokowniczej.

\section{Wtórne nowotwory otrzewnej (przerzuty otrzewnowe)}

3. Rak jelita grubego

Rozsiew śródotrzewnowy jest stwierdzany u 10-15\% chorych w czasie pierwotnej resekcji raka jelita grubego, a dodatkowo nawroty ograniczone jedynie do otrzewnej dotyczą kolejnych 10-15\% chorych [20]. Przeprowadzone badania, włączając $w$ to badania II fazy $i$ jedno badanie III fazy, wskazuja, że CCRS plus HIPEC u chorych z rozsiewem śródotrzewnowym raka jelita grubego pozwala osiągnąć medianę przeżyć wynoszącą 22-62 miesiące (całkowite przeżycia 5-letnie 11-48\%), ze wskaźnikiem $\mathrm{PCl}(\leq 20)$ jako istotnym czynnikiem rokowniczym [21]. Przeżycia te są istotnie dłuższe niż u chorych leczonych samą chemioterapią systemową. W badaniu III fazy, u chorych po CCRS plus HIPEC uzyskano medianę całkowitego przeżycia 22 miesiące, a 5-letnie przeżycia u $45 \%$ chorych, zaś w całej grupie (CCR0-2) odsetek ten wyniósł 20\% [22]. W grupie 151 chorych na raka jelita grubego z rozsiewem choroby ograniczonym do otrzewnej skojarzenie CCRS i HIPEC wiązało się z odsetkiem 5-letnich przeżyć całkowitych wynoszącym 40\% [23, 24], podobne są dane z rejestrów obejmujących ponad 500 chorych [3]. Na podstawie ostatnio ustalonego międzynarodowego uzgodnienia CCRS plus HIPEC jest postępowaniem z wyboru u chorych na raka jelita grubego z rozsiewem ograniczonym do otrzewnej [1]; najczęściej stosowanymi chemioterapeutykami są mitomycyna C oraz oksaliplatyna. Po zabiegu CCRS plus HIPEC chory powinien być kwalifikowany do dalszego leczenia systemowego. Istotne jest, aby kwalifikacja do leczenia za pomocą HIPEC była podejmowana na wczesnym etapie leczenia rozsiewu śródotrzewnowego, a nie jako terapia ratunkowa. Śródoperacyjnie stwierdzony wskaźnik PCI powyżej 20, brak możliwości CCRS do poziomu CCR 0-1, zły stan sprawności > 2 wg ECOG, objawowe wodobrzusze, konieczność wykonania rozległej resekcji wątroby z powodu przerzutów (lub > 3 przerzuty do wątroby), obecność nieusuniętej doszczętnie wznowy miejscowej, niedrożność dróg żółciowych lub moczowych, typ śluzowokomórkowy raka oraz progresja w czasie przedoperacyjnej chemioterapii systemowej stanowią podstawowe ograniczenia metody z uwagi na istotnie gorsze wyniki terapii [25]. Dodatkowo w ocenie zaawansowania zmian w otrzewnej w przypadku raka jelita grubego powinna być stosowana skala PSDS (Peritoneal Surface Disease Severity score) [26], która poza wartością $\mathrm{PCl}$ zawiera informacje na temat typu histologicznego oraz obecności objawów. Wyliczenie wskaźnika PSDS opiera się na sumowaniu wartości przypisanych do oceny skategoryzowanej wskaźnika $\mathrm{PCl}(\mathrm{PCl}<10-1$ punkt, PCl 10-20 - 3 punkty, $\mathrm{PCl}>20-7$ punktów), obecności objawów (brak objawów - 0 pkt, skąpoobjawowy przebieg - 1 pkt, objawy nasilone -6 pkt) oraz wynikach oceny histopatologicznej (G1 lub G2 N0 - 1 pkt, G2 N1-N2 - 3 pkt, G3 lub obecność utkania sygnetowatokomórkowego - 9 pkt). Do tak uzyskanej wartości punktów przypisano odpowiednie kategorie rokownicze: kategoria I: 1-4 punktów, II: 4-7 punktów, 
Tabela II . Ocena wskaźnika PSDS (Peritoneal Surface Disease Severity Score)

\begin{tabular}{|c|c|c|}
\hline Ocena kliniczna & $\begin{array}{l}\mathrm{PCl} \text { (na podstawie badań } \\
\text { obrazowych lub ocenione } \\
\text { w trakcie laparotomii) }\end{array}$ & $\begin{array}{l}\text { Histologia } \\
\text { guza }\end{array}$ \\
\hline Brak objawów & $P C l<10$ & $\begin{array}{l}\text { G1 } \\
\text { G2, N-, L-, V- }\end{array}$ \\
\hline 0 pkt & 1 pkt & 1 pkt \\
\hline $\begin{array}{l}\text { Objawy } \\
\text { o średnim } \\
\text { nasileniu }\end{array}$ & $\mathrm{PCl} 10-20$ & $\begin{array}{l}\mathrm{G} 2 \mathrm{~N}+ \\
\mathrm{i} / \mathrm{lub} \mathrm{L}+ \\
\mathrm{i} / \mathrm{lub} \mathrm{V}_{+}\end{array}$ \\
\hline 1 pkt & 3 pkt & 3 pkt \\
\hline $\begin{array}{l}\text { Objawy o dużym } \\
\text { nasileniu }\end{array}$ & $\mathrm{PCl}>20$ & $\begin{array}{l}\text { Każdy G3 } \\
\text { Każdy } \\
\text { sygntetowato- } \\
\text { komórkowy }\end{array}$ \\
\hline 6 pkt & 7 pkt & 9 pkt \\
\hline
\end{tabular}

Objawy o średnim nasileniu = niewielkie wodobrzusze, dobrze kontrolowane bóle brzucha, utrata masy ciała $<10 \%$

Objawy o dużym nasileniu = utrata masy ciała $>10 \%$, źle kontrolowane bóle brzucha, objawowe wodobrzusze, niedrożność

\begin{tabular}{ll}
\hline Wartość punktowa & Stopień zaawansowania wg PSDS \\
\hline $2-3$ & I \\
$4-7$ & II \\
$8-10$ & III \\
10 & IV \\
\hline
\end{tabular}

III: 8-10 punktów i IV: powyżej 10 punktów. Skalę PSDS przedstawia tabela II.W badaniach prospektywnych wykazano złe wyniki leczenia dla grupy IV, przy relatywnie korzystnych wynikach w pozostałych grupach chorych, stąd, poza ograniczeniem stosowania CRS i HIPEC u chorych z wysokim $\mathrm{PCl}$ powinno się ograniczyć stosowanie tej procedury do chorych z grup I-III wg PSDS.

4. Rak jajnika

Pomimo iż 60-80\% chorych na zaawansowanego raka jajnika odpowiada na wstępną chemioterapię opartą na cisplatynie, to u większości dochodzi do nawrotu choroby (u około $80 \%$ w postaci nawrotu śródotrzewnowego), a mediana przeżyć wynosi 12-25 miesięcy. Badania kohortowe i badania Il fazy, głównie u chorych z nawrotem śródotrzewnowym po leczeniu systemowym pierwszej lub drugiej linii, potwierdzają skuteczność CCRS plus HIPEC. Odsetek przeżyć 5-letnich wynosi od około $16 \%$ do nawet ponad $50 \%[27,28]$, co jest istotnie lepsze od danych archiwalnych u chorych leczonych jedynie chemioterapią. Najczęściej stosowana chemioterapia dootrzewnowa obejmuje cisplatynę (+/-doksorubicyna) i taksany. Dostępne dane wskazują na wydłużenie przeżyć wolnych od nawrotu choroby po zastosowaniu CCRS plus HIPEC, procedura ta powinna stanowić element leczenia skojarzonego z leczeniem systemowym, po CCRS plus HIPEC niezbędne jest wdrożenie chemioterapii [29]. W ostatnio opublikowanej serii 246 chorych leczonych z udziałem CCRS plus HIPEC w przypadku zmian prze- trwałych po leczeniu systemowym lub nawrotowych zmian śródotrzewnowych (pierwszy nawrót) w raku jajnika $[2,30]$ mediana przeżycia całkowitego wyniosła 49 miesięcy i wydaje się, że taka grupa chorych stanowi obecnie najlepsze wskazanie do zastosowania HIPEC, pod warunkiem osiągnięcia CCR 0-1 [30, 31]. W związku z powyższym proponowane wskazania obejmują leczenie odległych wznów śródotrzewnowych raka jajnika po leczeniu chirurgicznym i systemowym, chorych z przetrwałymi zmianami po laparotomii zwiadowczej i następowej chemioterapii oraz leczenie nawrotowego raka jajnika z rozsiewem śródotrzewnowym u pacjentek platynowrażliwych (minimum rok od pierwotnej operacji, pierwszy nawrót choroby).

\section{Wskazania zindywidualizowane lub będące przedmiotem badań do stosowania HIPEC}

1. Rak żołądka

U $10-20 \%$ chorych kwalifikowanych do potencjalnie radykalnej resekcji oraz u $20-50 \%$ chorych po resekcji raka żołądka stwierdza się rozsiew śródotrzewnowy. W większości badań chorych na raka żołądka poddanych CCRS plus HIPEC obserwowano medianę przeżycia nieprzekraczającą 15 miesięcy [2]. U chorych na raka żołądka opublikowano badanie III fazy [32] porównujące wyłącznie leczenie chirurgiczne z CCRS plus HIPEC u 68 chorych z rozsiewem śródotrzewnowym, w którym stwierdzono istotne wydłużenie przeżyć całkowitych z 6,5 do 11 miesięcy w grupie poddanej HIPEC (13,5 miesiąca w grupie, w której uzyskano CCR 0-1), szczególnie istotne $w$ grupie ze zwiększonym wskaźnikiem $\mathrm{PCl}$. W chwili obecnej wskazania do wykonywania HIPEC w tej grupie chorych powinny być starannie indywidualizowane i ograniczone jedynie do grupy, w której można uzyskać radykalną cytoredukcję CCRO, a wskaźnik PCI nie przekracza 6, szczególnie w grupie chorych po skutecznej chemioterapii neoadiuwantowej [33, 34]. Najczęściej stosowana jest mitomycyna C (+/- cisplatyna). Wskazania odnośnie profilaktycznej procedury HIPEC u chorych na raka żołądka o dużym ryzyku zrakowacenia otrzewnej nie są ostatecznie ustalone, jednak technikę tę można rozważać u chorych z dodatnim wynikiem badania cytologicznego popłuczyn z jamy otrzewnej, gdyż metaanaliza badań wskazuje na poprawę przeżyć chorych w takiej sytuacji klinicznej [35].

2. Również w rozsiewie śródotrzewnowym mięsaków tkanek miękkich jamy brzusznej, w przypadku możliwości radykalnego chirurgicznego usunięcia zmian śróodtrzewnowych (CCRS) i zastosowaniu HIPEC stwierdza się długoletnie przeżycia [36, 37], jednak dane te są bardzo ograniczone i nie zaleca się stosowania HIPEC w rozsiewie mięsaków w jamie brzusznej z wyjątkiem skojarzonego leczenia desmoplastycznych nowotworów 
drobnookrągłokomórkowych (DSRCT — desmoplastic small round cell tumor), gdy można wykonać maksymalną CCRS [38].

\section{Przeciwwskazania do stosowania HIPEC}

Nie wykazano korzyści z zastosowania CCRS plus HIPEC w rozsiewie śródotrzewnowym raka piersi i GIST, nie istnieją dane odnośnie raka trzustki [2]. Ustalone przeciwwskazania do zastosowania HIPEC stanowią: obecność przerzutów poza jamą otrzewnej, zły stan sprawności chorego, istotne choroby współistniejące, znaczne zaawansowanie miejscowe (wysoki > $20 \mathrm{PCl}$ z wyjątkiem pseudomyxoma peritonei lub zajęcie 5 z 6 regionów jamy brzusznej) — niemożność wykonania maksymalnej cytoredukcji $(C C R<2)$, wiek > 70 lat, zły stan odżywienia, nieresekcyjne przerzuty do wątroby. Przeciwwskazania względne obejmują wskaźnik masy ciała (Body Mass Index - BMI) > 40, stan po radioterapii na obszar miednicy, liczne wcześniejsze zabiegi w obrębie jamy brzusznej, cechy wielopoziomowej niedrożności przewodu pokarmowego, niedrożność dróg żółciowych lub moczowych, progresja po chemioterapii neoadiuwantowej.

\section{Podsumowanie}

Dootrzewnowa chemioterapia w hipertermii, będąca uzupełnieniem doszczętnej operacji cytoredukcyjnej, może stanowić u wybranych chorych cenną opcję terapeutyczną w trudnej onkologicznie sytuacji, jaką jest wieloogniskowy rozsiew nowotworowy do otrzewnej. Zastosowanie tej metody wymaga doświadczenia wielospecjalistycznego zespołu lekarskiego (chirurg, onkolog kliniczny), a także zaplecza diagnostycznego i leczniczego (oddziału intensywnej opieki medycznej) oraz zalecanego systemu do perfuzji wraz z przeszkolonym personelem średnim. Kwalifikacja do tej terapii musi obejmować wielospecjalistyczną ocenę w formie pisemnej, obejmującą minimum chirurgów/ginekologów onkologicznych oraz onkologów klinicznych. Powinno się prowadzić prospektywne obserwacje wyników oraz kontrolę występowania powikłań po leczeniu.

Zgodnie z istniejącymi zaleceniami międzynarodowymi $[1,39]$ CCRS oraz HIPEC jest standardowo stosowany u chorych z przerzutami do otrzewnej raka jelita grubego lub raka jajnika (gdy $\mathrm{PCl}<20$ ) oraz u chorych na międzybłoniaka lub śluzaka rzekomego otrzewnej.

Zindywidualizowane wskazania obejmują chorych na raka żołądka i DSRCT.

\section{Konflikt interesu: nie zgłoszono}

Prof. dr hab. n. med. Piotr Rutkowski

Klinika Nowotworów Tkanek Miękkich i Kości

Centrum Onkologii - Instytut

im. Marii Skłodowskiej-Curie w Warszawie

ul. Roentgena 5, 02-781 Warszawa

Otrzymano i przyjęto do druku: 24 września 2014 r.

\section{Piśmiennictwo}

1. Esquivel J, Sticca R, Sugarbaker P i wsp. Cytoreductive surgery and hyperthermic intraperitoneal chemotherapy in the management of peritoneal surface malignancies of colonic origin: a consensus statement. Society of Surgical Oncology. Ann Surg Oncol 2007; 14: 128-133.

2. Elias D, Goere D, Dumont F i wsp. Role of hyperthermic intraoperative peritoneal chemotherapy in the management of peritoneal metastases. Eur J Cancer 2014; 50: 332-340.

3. Roviello F, Pinto E, Corso G i wsp. Safety and potential benefit of hyperthermic intraperitoneal chemotherapy (HIPEC) in peritoneal carcinomatosis from primary or recurrent ovarian cancer. J Surg Oncol 2010; 102: 663-670.

4. Ozols RF, Locker GY, Doroshow JH i wsp. Pharmacokinetics of adriamycin and tissue penetration in murine ovarian cancer. Cancer Res 1979; 39 : 3209-3214.

5. Los G, Verdegaal EM, Mutsaers PH i wsp. Penetration of carboplatin and cisplatin into rat peritoneal tumor nodules after intraperitoneal chemotherapy. Cancer Chemother Pharmacol 1991; 28: 159-165.

6. Baratti D, Kusamura $S$, Cabras AD i wsp. Cytoreductive surgery with selective versus complete parietal peritonectomy followed by hyperthermic intraperitoneal chemotherapy in patients with diffuse malignant peritoneal mesothelioma: a controlled study. Ann Surg Oncol 2012; 19: 1416-1424.

7. Elias D, Bonnay M, Puizillou JM i wsp. Heated intra-operative intraperitoneal oxaliplatin after complete resection of peritoneal carcinomatosis: pharmacokinetics and tissue distribution. Ann Oncol 2002; 13:267-272.

8. Turaga K, Levine E, Barone R i wsp. Consensus guidelines from The American Society of Peritoneal Surface Malignancies on standardizing the delivery of hyperthermic intraperitoneal chemotherapy (HIPEC) in colorectal cancer patients in the United States. Ann Surg Oncol 2014; 21: 1501-1505.

9. Sorensen O, Flatmark K, Reed W i wsp. Evaluation of complete cytoreductive surgery and two intraperitoneal chemotherapy techniques in Pseudomyxoma peritonei. Eur J Surg Oncol 2012; 38: 969-976.

10. Sugarbaker PH. Review of a personal experience in the management of carcinomatosis and sarcomatosis. Jpn J Clin Oncol 2001;31:573-583.

11. Mohamed F, Cecil T, Moran B i wsp. A new standard of care for the management of peritoneal surface malignancy. Curr Oncol 2011; 18: e84-96.

12. Symonides $M$, Łuniewska $M$, Fortuna $M$ i wsp. Uwagi praktyczne do śródoperacyjnej anestezjii u pacjentów operowanych z zastosowaniem dootrzewnowej perfuzyjnej chemioterapii w warunkach hipertermii-seria 60 przypadków. Curr Gynecol Oncol 2013; 11: 255-263.

13. Chua TC, Martin S, Saxena A i wsp. Evaluation of the cost-effectiveness of cytoreductive surgery and hyperthermic intraperitoneal chemotherapy (peritonectomy) at the St George Hospital peritoneal surface malignancy program. Ann Surg 2010; 251: 323-329.

14. Yan TD, Deraco M, Baratti D i wsp. Cytoreductive surgery and hyperthermic intraperitoneal chemotherapy for malignant peritoneal mesothelioma: multi-institutional experience. J Clin Oncol 2009; 27: 6237-6242.

15. Yan TD, Black D, Sugarbaker PH i wsp. A systematic review and meta-analysis of the randomized controlled trials on adjuvant intraperitoneal chemotherapy for resectable gastric cancer. Ann Surg Oncol 2007; 14: 2702-2713.

16. Alexander HR, Jr., Bartlett DL, Pingpank JF i wsp. Treatment factors associated with long-term survival after cytoreductive surgery and regional chemotherapy for patients with malignant peritoneal mesothelioma. Surgery 2013; 153: 779-786.

17. Chua TC, Moran BJ, Sugarbaker PH i wsp. Early-and long-term outcome data of patients with pseudomyxoma peritonei from appendiceal origin treated by a strategy of cytoreductive surgery and hyperthermic intraperitoneal chemotherapy. J Clin Oncol 2012; 30: 2449-2456.

18. Sorensen O, Flatmark K, Reed W i wsp. Evaluation of complete cytoreductive surgery and two intraperitoneal chemotherapy techniques in pseudomyxoma peritonei. Eur J Surg Oncol 2012; 38: 969-976.

19. Cole KL, Choudry HA, Jones HL i wsp. Critical role of hyperthermic intraperitoneal chemoperfusion in the treatment of a patient with Pseudomyxoma peritonei. J Surg Oncol 2012; 106: 513-516.

20. Roviello F, Caruso S, Marrelli D i wsp. Treatment of peritoneal carcinomatosis with cytoreductive surgery and hyperthermic intraperitoneal chemotherapy: state of the art and future developments. Surg Oncol 2011; 20: e38-54.

21. Yan TD, Black D, Savady R i wsp. Systematic review on the efficacy of cytoreductive surgery combined with perioperative intraperitoneal chemotherapy for peritoneal carcinomatosis from colorectal carcinoma. J Clin Oncol 2006; 24: 4011-4019. 
22. Verwaal VJ, Bruin S, Boot H i wsp. 8-year follow-up of randomized trial: cytoreduction and hyperthermic intraperitoneal chemotherapy versus systemic chemotherapy in patients with peritoneal carcinomatosis of colorectal cancer. Ann Surg Oncol 2008; 15: 2426-2432.

23. Cashin PH, Graf W, Nygren P i wsp. Cytoreductive surgery and intraperitoneal chemotherapy for colorectal peritoneal carcinomatosis: prognosis and treatment of recurrences in a cohort study. Eur J Surg Oncol 2012; 38: 509-515.

24. Glehen O, Kwiatkowski F, Sugarbaker PH i wsp. Cytoreductive surgery combined with perioperative intraperitoneal chemotherapy for the management of peritoneal carcinomatosis from colorectal cancer: a multi-institutional study. J Clin Oncol 2004; 22: 3284-3292.

25. Esquivel J, Lowy AM, Markman M i wsp. The American Society of Peritoneal Surface Malignancies (ASPSM) Multiinstitution Evaluation of the Peritoneal Surface Disease Severity Score (PSDSS) in 1,013 Patients with Colorectal Cancer with Peritoneal Carcinomatosis. Ann Surg Oncol 2014 May 23 [Epub ahead of print].

26. Pelz JO, Stojadinovic A, Nissan A i wsp. Evaluation of a peritoneal surface disease severity score in patients with colon cancer with peritoneal carcinomatosis. J Surg Oncol 2009; 99: 9-15.

27. Tentes AA, Kakolyris S, Kyziridis D i wsp. Cytoreductive surgery combined with hyperthermic intraperitoneal intraoperative chemotherapy in the treatment of advanced epithelial ovarian cancer. J Oncol 2012; 2012: 358341.

28. Di Giorgio A, Naticchioni E, Biacchi D i wsp. Cytoreductive surgery (peritonectomy procedures) combined with hyperthermic intraperitoneal chemotherapy (HIPEC) in the treatment of diffuse peritoneal carcinomatosis from ovarian cancer. Cancer 2008; 113: 315-325.

29. Śpiewankiewicz B, Osuch B, Kuśnierz J i wsp. Wstępna ocena przydatności dootrzewnowej perfuzyjnej chemioterapii w warunkach hipertermii (HIPEC) u chorych z nowotworowym rozsiewem wewnątrzotrzewnowym. Curr Gynecol Oncol 2013; 11: 33-41.

30. Bakrin N, Cotte E, Golfier F i wsp. Cytoreductive surgery and hyperthermic intraperitoneal chemotherapy (HIPEC) for persistent and recurrent advanced ovarian carcinoma: a multicenter, prospective study of 246 patients. Ann Surg Oncol 2012; 19: 4052-4058.

31. Cascales Campos P, Gil J, Parrilla P. Morbidity and mortality outcomes of cytoreductive surgery and hyperthermic intraperitoneal chemotherapy in patients with primary and recurrent advanced ovarian cancer. Eur J Surg Oncol 2014; 40: 970-975.

32. Yang XJ, Huang CQ, Suo T i wsp. Cytoreductive surgery and hyperthermic intraperitoneal chemotherapy improves survival of patients with peritoneal carcinomatosis from gastric cancer: final results of a phase III randomized clinical trial. Ann Surg Oncol 2011; 18: 1575-1581.

33. Montori G, Coccolini F, Ceresoli M i wsp. The treatment of peritoneal carcinomatosis in advanced gastric cancer: state of the art. Int J Surg Oncol 2014; 2014: 912418.

34. Yonemura Y, Elnemr A, Endou Y i wsp. Effects of neoadjuvant intraperitoneal/systemic chemotherapy (bidirectional chemotherapy) for the treatment of patients with peritoneal metastasis from gastric cancer. Int J Surg Oncol 2012; 2012: 148420.

35. Roviello F, Caruso S, Neri A i wsp. Treatment and prevention of peritoneal carcinomatosis from gastric cancer by cytoreductive surgery and hyperthermic intraperitoneal chemotherapy: overview and rationale. Eur J Surg Oncol 2013; 39: 1309-1316.

36. Salti Gl, Ailabouni L, Undevia S. Cytoreductive surgery and hyperthermic intraperitoneal chemotherapy for the treatment of peritoneal sarcomatosis. Ann Surg Oncol 2012; 19: 1410-1415.

37. Baratti D, Pennacchioli E, Kusamura S i wsp. Peritoneal sarcomatosis: is there a subset of patients who may benefit from cytoreductive surgery and hyperthermic intraperitoneal chemotherapy? Ann Surg Oncol 2010;17: 3220-3228.

38. Hayes-Jordan A, Green HL, Lin H i wsp. Complete cytoreduction and HIPEC improves survival in desmoplastic small round cell tumor. Ann Surg Oncol 2014; 21: 220-224.

39. Trimble EL, Christian MC. National Cancer Institute-United States strategy regarding intraperitoneal chemotherapy for ovarian cancer. Int J Gynecol Cancer 2008;18 Suppl 1: 26-28. 